\title{
Makna "Salam" Dalam Surat-Surat Paulus Dan Implementasinya Bagi Pelayan Tuhan Saat Ini
}

\author{
Zakaria Harefa $^{1 *}$, Ceria*2, Imayanti Nainggolan3, Edison Pangreho ${ }^{4}$, Juliati ${ }^{5}$ \\ 1,2,3,4, 5 Mahasiswa Prodi Magister Teologi, STT Real Batam \\ ceria2988@gmail.com
}

\begin{abstract}
Paul was one of the apostles who had an important role in the history of Christianity. Most of the books of the New Testament were written by Paul. The peculiarity of Paul's writing style raises the curiosity of whether the meaning of Paul's writings, the use of the word greeting in his writing is seen as having a deep meaning, therefore it is necessary to further explore what the meaning of greetings in Paul's letters is and what is its implementation for God's servants today. The research method in writing this journal is a descriptive qualitative method, with a literature approach and is classified as a library research. It can be concluded that the meaning of greetings contained in Paul's letters becomes the ideal standard for every servant of God in his ministry.

Keywords: Greetings, Paul's Letter, Servant of God
\end{abstract}

\begin{abstract}
Abstrak
Paulus merupakan salah rasul yang memiliki peran penting dalam sejarah kekristenan. Hampir Sebagian besar dari kitab Perjanjian Baru adalah buah karya tulisan Paulus. Kekhasan gaya penulisan Paulus menimbulkan rasa ingin tahu apakah makna dari setiap tulisan Paulus, penggunaan kata salam dalam tulisannya dipandang memiliki makna yang dalam, oleh karenanya perlu kajan lebih jauh tentang apakah makna salam dalam surat-surat Paulus dan apakah implementasinya bagi pelayan Tuhan masa kini. Metode penelitian dalam penulisan jurnal ini adalah metode kualitatif deskriptif, dengan pendekatan literatur dan tergolong dalam penelitian perpustakaan. Hasil penelitian menemukan bahwa makna salam yang terkandung dalam surat-surat Paulus menjadi standar ideal bagi setiap hamba Tuhan dalam pelayanannya.

Kata kunci: Salam, Surat Paulus, Pelayan Tuhan
\end{abstract}




\section{PENDAHULUAN}

Paulus lahir di Tarsus, dalam surat-suratnya dikitab Perjanjian Baru, Paulus memperkenalkan dirinya sebagai seorang Yahudi dari suku Benyamin, namun Paulus juga secara sah memiliki kewarganegaraaan Romawi sejak lahir ditulis dalam Kis 22:28 kemungkinan besar kewarganegaraan ini diberikan kepada keluarganya karena pengabdian orang tua atau leluhurnya pada pemerintahan Romawi. ${ }^{1}$ Hampir sebagian dari kitab Perjanjian Baru yakni 13 kitab, mencantumkan nama Paulus sebagai penulisnya. Selain itu, dalam kitab lainnya yaitu Kisah Para Rasul juga berisi tentang sosok yang sama, tentang bagaimana ia menjadi rasul, dan bagaimana ia memberitakan injil keseluruh wilayah kekaisaran Roma. ${ }^{2}$

Paulus merupakan tokoh Alkitab yang memiliki peran penting dalam sejarah kekristenan. Seperti yang di bahas sebelunnya, setidaknya ada delapan surat yang ditulis oleh Paulus sendiri. Sebagai seorang rasul, Paulus mengetahui bahwa tugas terpenting didalam hidupnya adalah memberitakan injil atau berita perdamaian Allah kepada setiap orang. Hal itulah yang menjadi dasar bagi Paulus untuk lebih banyak menggunakan kata Yesus Kristus ataupun Kristus Yesus. Paulus juga mewartakan Injil dengan segala kepandaian yang ada padanya, yang ia terima dari Pendidikan Yunani di Tarsus maupun dari teologi yang dipelajarinya dari Gamaliel di Yerusalem. Willi Marxsen dalam bukunya mengatakan bahwa delapan kitab yang ditulis oleh rasul Paulus adalah 1 dan 2 Tesalonika, Galatia, Filipi, Filemon, 1 dan 2 Korintus, dan Roma, sedangkan Kolose, Efesus, 1 dan 2 Timotius dan Titus dimasukkan dalam kategori surat lain yang memuat nama Paulus sebagai penulisnya namun masih diperdebatkan hingga saat ini. ${ }^{3}$ Namun menurut Budiman dalam bukunya, 1 dan 2 Timotius adalah surat-surat pastoral yang berisi petunjuk mengenai bagaimana jemaat Tuhan harus digembalakan. Beberapa alasannya adalah dimana sesuai dengan kebiasaan Paulus untuk mendikte surat-suratnya ia juga berbuat demikian untuk surat Pastoral, juga jika dilihat dari ciri khas gaya penulisan maupun bahasa menegaskan jika surat ini merupakan surat dari Paulus sendiri. ${ }^{4}$

\footnotetext{
${ }^{1}$ Jonar Situmorang, "Model Misi Perkotaan Rasul Paulus Di Korintus," Missio Ecclesiae 7, no. 2 (2018): hal. 191.

${ }^{2}$ Robert G Bratcher, Surat-Surat Paulus Kepada Jemaat Di Kolose Kepada Filemon (Jakarta: LAI dan Yayasan Karunia Bakti Budaya Indonesia, 2019). hal 3-4.

${ }^{3}$ Willi Marxsen, Pengantar Perjanjian Baru: Pendekatan Kritis Terhadap Masalah-Masalahnya (Jakarta: Gunung Mulia, 2008). Hal. 1.

${ }^{4}$ R. Budiman, Surat 1\& 2 Timotius Dan Titus (Jakarta: Bpk Gunung Mulia, 2016).hal. 9-11.
} 
Surat-surat Paulus memberikan gambaran tentang kehidupan orang Kristen mula-mula, yaitu mereka yang berusaha memahami apa maksud Yesus dan juga pengajaran-Nya. ${ }^{5}$ Pengajaran Paulus juga mengambarkan tentang budaya dan kehidupan sosial masyarakat pada zamannya. Setiap surat Paulus diawali dengan salam sebagaimana lazimnya surat-surat pada abad yang pertama. Diawali dengan perkenalan diri penulis surat itu sendiri yang merujuk kepada identitasnya dan juga penjelasan tentang kepada siapa surat tersebut ditujukan. Sosok Paulus memiliki peran penting dalam pertumbuhan dan perkembangan kekristenan mula-mula. Ia berkotbah dan mengajar di banyak tempat dalam perjalanan melintasi Laut Tengah. Sejumlah suratnya di tunjukkan kepada jemaat-jemaat yang pernah ia temui sebelumnya saat memberitakan kabar baik, dan juga kepada jemaat atau seseorang yang diharapkan untuk ia temui dikemudian hari.

Ada beberapa orang yang beranggapan jika salam bukanlah merupakan bagian yang penting. Salam merupakan ucapan biasa sehingga kurang di perdulikan makna yang ada didalamnya. Namun berbeda dengan Paulus, hampir disetiap suratnya selalu di buka dan ditutup dengan salam dan hal ini bukanlah sekedar kebiasaan atau norma pergaulan saja, melainkan Paulus memiliki maksud tersendiri dalam setiap salamnya. ${ }^{6}$

Salam merupakan cara bagi seseorang untuk mengawali komunikasi dengan orang lain, menunjukan perhatian, dalam hubungan sosial antar individu atau kelompok orang yang dipengaruhi oleh budaya dan situasi yang dapat di ekspresikan melalui gerakan maupun ucapan atau gabungan dari keduanya. salam juga menunjukan bagaimana menempatkan atau menilai orang lain, dan juga salam menunjukan harapan berkat bagi orang lain. ${ }^{7}$ Begitu juga dengan salam dalam surat Paulus yang memiliki makna teologi dam misiologi yang padat, dan salam merupakan bagian pendahuluan dalam surat yang merupakan sesuatu hal yang penting untuk diketahui sebab pendahuluan menentukan suasana dari surat itu sendiri dan maksud dari surat tersebut hal ini menjadi sesuatu hal yang menarik untuk digali dan di pelajari yaitu apakah makna dari "salam" dalam surat-surat Paulus?, dan bagaimana implemetasinya bagi pelayan Tuhan saat ini?. Hal inilah yang membuat penulis tertarik untuk mengaali lebih dalam tentang makna "salam" dalam

${ }^{5}$ Wenas Kalangit, "SURAT-SURAT PAULUS," Gereja Kristen Indonesia, last modified 2007, http://www.gki-kavpolri.or.id/site/surat-surat-paulus-oleh-dr-wenaskalangit/. Diakses 27 April 2021.

6 "Salam," https://saatteduh.wordpress.com/2019/05/09/salam/. Diakses 27 April 2021.

7 "Salam," Wikipedia Ensiklopedia Bebas, https://id.wikipedia.org/wiki/Salam. Diakses 27 April 2021 
surat-surat Paulus dan implementasi bagi pelayan Tuhan saat ini" sehingga seseorang bisa memahami makna yang benar yang menuntun dalam mempelajari surat-surat Paulus tersebut serta bermanfaat bagi pelayan Tuhan saat ini.

\section{METODE}

Metode penelitian, penulis menggunakan pendekatan metode penelitian kualitatif deskriptif, dengan pendekatan literatur dan tergolong dalam penelitian perpustakaan, dan penelitian ini dilakukan dengan cara mempelajari setiap data berupa dokumen atau penelitian terdahulu dari berbagai buku yang berkaitan dengan makna salam dalam surat-surat Paulus, guna memperoleh gambaran yang jelas tentang makna salam dalam surat Paulus yang kemudian bagaimana makna tersebut dapat di implementasikan dalam kehidupan pelayanan saat ini Demikian juga Sugiono mengungkapkan bahwa penelitian deskriptif kualitatif adalah penelitian yang berusaha untuk menuturkan pemecahan masalah yang ada berdasar data-data mengikuti teknik pengolahan dan analisis data. ${ }^{8}$

\section{HASIL DAN PEMBAHASAN}

\section{Makna "Salam" Dalam Surat-Surat Paulus}

Salam dalam bahasa Ibrani adalah "haag" yang memiliki pengertian "memberi salam" dan "memberi berkat, serta memberi kekuatan kepada orang yang layak menerimanya bandingkan dengan Matius 10:13. Pesan salam juga lazim dalam surat- menyurat, tampa harus melalui perjumpaan pribadi. Palulus dalam beberapa suratnya menggunakan kata benda aspasmos, namun yang paling sering ia gunakan adalah kata kerja aspazomai, yang merupakan rumusan yang biasa dalam surat menyurat Yunani pada zamannya, yaitu salam yang terdapat nama penulisnya langsung atau orang lain secara khusus seperti dalam Roma 16:1-27. ${ }^{9}$

Seperti yang telah di jelaskan sebelumnya Paulus memiliki sepuluh kitab yang ditulis oleh rasul Paulus adalah 1 dan 2 Tesalonika, Galatia, Filipi, Filemon, 1 dan 2 Korintus, Roma, dan 1\&2 Timotius Sementara itu, Kolose, Efesus, dan Titus dimasukkan dalam kategori surat lain yang memuat nama Paulus sebagai penulisnya. Berikut adalah makna salam dari masing-masing kitab tersebut.

Pertama, makna salam dalam 1 dan 2 Tesalonika dimana Paulus tidak menyebut dirinya sebagai rasul didalam salamnya. Hal ini disebabkan karena mereka sangat mengasihi Paulus dan mereka percaya dengan sungguh jika

${ }^{8}$ Sugiono, Memahami Penelitian Kualitatif(Bandung: CV Alfabeta, 2016). Hal.

\footnotetext{
9 "Studi Kamus," Alkitab Sabda.
} 
Paulus adalah seorang rasul Kristus, masih sama dengan kebanyakan dari salam Paulus di kitab sebelumnya rasul Paulus memakai istilah kasih karunia dan damai sejahtera datang dari Allah Bapa dan Tuhan Yesus Kristus dimana kasih karunia pada dasarnya berarti "yang mendatangkan suka cita yaitu kemurahan dan teristimewa kemurahan Allah yang memperlengkapi segala keperluan rohani manusia dan damai sejahtera yang merupakan pemberian Allah yang merupakan hasil dari kasih karunia jika kasih karunia tersebut di terima oleh orang berdosa. Itulah doa Paulus untuk orang salah di Tesalonika. ${ }^{10}$

Kedua, Makna salam dalam surat Galatia adalah Paulus ingin menjelaskan tentang otoritas kerasulan yang ia dapatkan oleh karena Yesus Kristus. Hal ini di karenakan ada peristiwa yang terjadi pada jemaat di Galatia bermunculan ajaran- ajaran yang bertentangan dengan ajaran Kristus. Adan beberapa dari pengajaran tersebut mengajarakan bahwa sunat adalah keharusan bagi orang Kristen yang baru bertobat di Galatia (Galatia 1:6-7). Bahkan sampai kepada meragukan kerasulan Paulus dan juga ajaran-ajaran yang dibawa oleh Paulus. Surat Galatia memuat nama pengirim yaitu Paulus sendiri di ayat yang pertama, dan bersama dengan saudara-saudara yang bersama dengan dia (ayat ke 2). Penerima surat tersebut adalah jemaat Galatia. Pada ayat yang ke 3 paulus mengucapkan kalimat berkat yang merupakan bagian salam pada pembukaan khas gereja kuno dalam pendahuluan suratnya yaitu Kasih Karunia "Charis" dan Damai Sejahtera "Eirene" yang merupakan harapan Paulus untuk menjadi pengalaman hidup jemaat saat itu. ${ }^{11}$

Ketiga, salam dalam kitab Filipi 1:1-2 dimulai dengan Timotius sebagai kawan penulis surat ini, akan tetapi di ayat 1:3, 12-14, 16-26) nyata bahwa Paulus sendiri yang menulisnya. Namun adanya hubungan di antara kedua sebagai kawan sekerja maka Paulus menyebutnya sebagai kawan penulis, dan kata hamba dalam ayat satu menyatakan jika Paulus dan Timotius adalah hamba Kristus, namun kata hamba tersebut berbada artinya dengan budak melainkan hamba Kristus berarti menjadi orang yang merdeka dan hamba Kristus adalah orang yang di kasihi (Yoh 15:15), orang yang di akui dan di terima sebagai anak sehingga hamba-hamba Kristus melakukan pelayanan mereka dengan sukacita. Dalam ayat berikutnya Paulus dan Timotius sampaikan salam kasih karuna dan damai sejahtera dari Allah, Bapa kita Tuhan Yesus Kristus menyertai kamu, salam ini mempunyai arti yang dalam. Kasih Karunia (Yunanai: Kharis) memiliki makna kemurahan,

${ }^{10}$ J. Wesley Brill, Tafsiran Surat Tesalonika (Bandung: Yayasan Kalam Hidup, 2008). hal 2-3.

11 "Studi Kamus." 
kebaikan, anugerah Tuhan Allah. Karena kasih karunia-Nya kepada manusia yang berdosa ialah dasar dimana jemaat itu berdiri. Damai sejahtera (Yunani: Eirene) bermakna keselamatan dan kebahagian yang menyatakan perdamaian antara Allah dan manusia, dan manusia dengan sesamanya, sedangkan kesejahteraan dalam arti yang luas adalah suasana yang ada di dalam jemaat. Hal ini dan segala hal yang baik tersebut berasal dari Allah, Bapa kita dan Tuhan Yesus Kristus. ${ }^{12}$

Keempat, makna salam dalam kitab filemon 1:1-3 Ayat 1: pada dasarnya surat ini merupakan surat pribadi, sehingga Paulus tidak mengunakan gelar resminya seperti "apostoos" (rasul) atau dulos (hamba) tetapi ia menyebut dirinya sebagai “desmios Kristou Yesou (tahanan Kristus Yesus). Paulus ingin menunjukan bahwa ia ingin berbicara dari teman ke teman dan bukan secara resmi, dengan menyebut dirinya sebagai "tahanan kristus Paulus ingin menunjukan situasi yang jelas tentang apa yang ia alami. Penerima surat ini adalah Filemon yang di sebut oleh Paulus sebagai teman sekerja, seseorang yang di kasihi Allah, di panggil untuk meneruskan kasih yang telai ia terima dari Onesimus sang budak yang telah bertobat

Diayat yang ke dua, Paulus memberikan salam kepada Apfia, Arkhipus, dan kepada semua jemaat yang berkumpul di rumah Filemon walaupun jemaat di rumah Filemon tersebut tidak disebutkan sebagai penerima surat tersebut, tetapi jelas salam yang di berikan Paulus menunjukan pentingnya surat tersebut bagi mereka yang ada hubungannya dengan kepulangan Onesimus. Sedangkan Apfia sendiri merupakan nama umum di Phrygia seorang saudari dari Filemon, dan Akhipus menurut kolose 4:17 adalah seseorang yang memiliki jabatan tinggi dan penting dan juga Paulus menyebutnya sebagai "teman seperjuangan" (sustratiootees). Di ayat yang ke tiga, Paulus dalam suratnya selalu menggunakan ucapan selamat "charis" (kasih karunia) dan memberikan suatu pengertian baru yang bercirikan pemahaman teologis kristiani. Ungkapan salam kasih karunia selalu dihubungkan dengan salam damai sejahtera. kasih karunia "charis" merupakan salah satu istilah penting dalam teologi Paulus, hal ini dikarenakan istilah “charis' di gunakan sehubungan dengan karya keselamatan Yesus di kayu salib (Roma 3:23-24). ${ }^{13}$

Kelima, makna salam dalm surat 1 dan 2 Korintus, dimana ucapan salam tersebut ada diawal dan di penutup surat yang merupakan salah satu ciri dari semua surat-surat yang di tulis oleh Paulus. Paulus sendiri telah tinggal

${ }^{12}$ J.L.CH. Abineno, Surat Filipi (Jakarta: Bpk Gunung Mulia, 2015). hal. 5.

${ }^{13}$ Rainer Scheunemann, Surat Paulus Kepada FILEMON (Jakarta: Bpk Gunung Mulia, 2016). hal 30. 
dan berdagang di Korintus, dan pada perjalanan misi yang kedua (Kis 18:118). Ia mendirikan gereja di sana. Ia juga menerima surat dari orang Kristen di Korintus tentang laporan yang berkaitan dengan masalah yang di hadapi warga jemaat. Paulus membuka suratnya dengan ucapan salam yang diawali dengan perkenalan dirinya dan temannya yang bernama Sostenes, juga Timotius di suratnya yang kedua. Sambutan hangat disampaikan Paulus sebagai saudara didalam Tuhan untuk jemaat Korintus. Dalam penyampainnya Paulus memberikan penegasan tentang dirinya yang berbada dengan surat-suratnya ditempat lain yaitu "oleh kehendak Allah dipanggil menjadi Rasul Kristus Yesus". Hal ini di karenakan surat ini berisi teguran yang serius untuk jemaat Korintus, dimana situasi jemaat saat itu sedang menghadapi masa sulit sehingga membutuhkan bantuan semangat serta keadilan bagi kebutuhan spiritual dan mental jemaat saat itu, serta Paulus senantiasa mengikut sertakan Yesus Kristus untuk menghadapi masa sulit tersebut. kedua Paulus berbicara tentang jemaat Allah di Korintus dimana hal ini menjelaskan tentang jemaat dimanapun berada merupakan bagian dari jemaat Allah hal inilah yang menyatukan jemaat dimanapun berada, Paulus juga menekankan tentang orang-orang kudus dalam Kristus Yesus yang menyelipkan makna tentang pengorbanan Yesus sehingga semua orang Kristen yang percaya adalah milik Allah, dan wajib menunjukan karakter dan kehidupan yang benar dan bermutu, serta berbeda dengan orang yang belum mengenal Yesus. ${ }^{14}$ Makna salam lainnya juga terdapat di akhir surat Paulus dalam 1 Korintus 16:19-24 dan 2 Korintus 13:11-13, hal ini memperlihatkan sisi Paulus yang sekalipun merupakan sosok yang tegas dan pemberani akan tetapi ia memiliki sisi lemah lembut dan rendah hati. Hal ini dilihat dari surat-surat yang ia tuliskan selain membuka dengan salam ia juga menutup suratnya dengan salam dari semua jemaat di Asia kecil dan saudara-saudara yang lain kepada jemaat di Korintus. Kemudian Paulus mengakhiri salamnya dengan penegasan tentang dirinya dengan kata-kata peringatan bahwa ia akan datang kembali ke Korintus dan membuat pernyataan yang akan ia buktikan jika situasi buruk saat itu tidak boleh berjalan terus dan harus di hadapi serta keinginannya supaya jemaat melakukan hal-hal yang baik, jika mereka melakukannya, ia tidak pernah menggunakan kekuasaannya sebagai rasul dan tidak akan ada kekecewaan baginya melainkan ada sukacita yang dalam yang rasul Paulus rasakan. Sebab segala sesuatu yang ia lakukan adalah untuk membangun dan bukan untuk menghancurkan. Disiplin harus selalu diarahkan untuk membangun seseorang

${ }^{14}$ William Barclay, Pemahaman Alkitab Setiap Hari; Surat 1dan 2 Korintus (Jakarta: Bpk Gunung Mulia, 2012).hal 23-26. 
bukan malah menjatuhkan. Paulus juga menuliskan harapannya supaya jemaat maju kearah kesempurnaan, mendengarkan nasihat yang di berikan serta hidup dalam suasana seia-sekata dengan damai tersebut dan dorongan kepada jemaat untuk tetap kuat, karena Kasih Karunia "Kharis" senantiasa menyertai mereka. ${ }^{15}$

Keenam, Makna salam dalam kitab Roma 1:1-7, kitab Roma di awali dengan salam, seperti layaknya dan umumnya kebudayaan Yunani jika digali lebih dalam. Cranfileld dalam Deve Hagelberg menyatakan jika salam dalam tulisan Paulus tersebut memiliki suatu kepentingan karena menjadi saluran untuk menceritakan maksud dari surat itu dan juga tentang pelayanan Paulus, salam tersebut penuh dengan Teologi dan misiologi yang padat.

Dari antara semua surat-surat Paulus, surat Roma memiliki perbedaan yang mencolok. Paulus memakai pendekatan yang berbeda dalam penulisan surat Roma, ini karena Paulus sendiri belum pernah bertemu secara fisik dengan jemaat di Roma dan tidak berhubungan langsung dengan jemaatnya. Hal ini dengan sendirinya menjelaskan mengapa dalam surat Roma ada sedikit masalah praktis yang tidak biasanya disinggung Paulus dalam surat-surat lainnya. Paulus dengan bijaksana dan kasih, memulai dengan suatu pujian, ia menceritakan kepada mereka bahwa ia bersyukur kepada Allah karena iman mereka telah dikenal keseluruh penjuru dunia. ${ }^{16}$ Inilah yang menjadi pertanda salam dalam surat Roma dimaknai sebagai suatu upaya Paulus membangun kedekatan dengan jemaat meskipun ia belum secara langsung bertemu atau mengenal baik jemaat tersebut. Paulus lebih memilih menggunakan pujian daripada sebuah kritik untuk membangun kedekatan kepada jemaat agar maksud dan tujuan Paulus dalam surat tersebut dapat diterima dan dipahami dengan baik oleh jemaaat di Roma.

Dilihat dalam ayat 1 Paulus memperkenalkan dirinya sebagai rasul dan memilih agar dia melakukan tugas tersebut dan dikuduskan atau dikhususkan dan memiliki tugas yaitu memberitakan injil dan hal ini juga tersirat dalam pasal 1:5. Injil yang dimaksud dijelaskan dalam ayat 3-4 yaitu Tuhan Yesus yang merupakan inti dari ijil Allah, Yesus yang benar-benar manusia sejati dan Ia pun benar-benar Allah yang sejati di ayat ke-5. Melalui Tuhan Yesus Paulus memperoleh kasih karunia yang menyelamatkan dan juga jabatan seorang rasulyang di percayakan kepadanya adalah penginjilan sedunia sesuai dengan konteks ayat ini da $\mathrm{n}$ tujuan utamanya dimulai dari wilayah spanyol (Roma 15:22-24) agar mereka taat dan percaya, taat yang

${ }^{15}$ Ibid. hal. 464.

${ }^{16}$ William Barclay, Pemahaman Alkitab Setiap Hari; Surat Roma (Jakarta: Bpk Gunung Mulia, 2007).hal. 27. 
dimaksud adalah ketaatan kepada iman, otoritas iman, dan kesetiaan kepada Allah. Dalam atyat yang ke 6, alasan Paulus melayani mereka adalah kerena jemaat Roma walapun mereka bukan Yahudi tapi mereka juga harus turut memiliki bagian dalam melayani Paulus. Pasal 1:1-6 secara struktur menerangkan si pengirim surat sedangkan di ayat ke 7 menjelaskan penerima surat. Paulus mengantikan kata "Khairen" salam yang biasanya dipakai dalam surat Yunani menjadi kata "kharis" kasih karunia yang merupakan gagasan penting dalam surat Paulus yang di pakai sebanyak 24 kali dalam surat Roma dan merupakan inti injil Kristus dan damai sejahtera adalah berkat dari Allah bagi orang yang terpanggil karena melalui kasih karunialah kita memperoleh damai sejahtera. Dalam Roma 1:1-7 ia mengemukakan banyak hal yang berkaitan dengan bebannya terhadap mereka.

Salam dan penghargaan kepada hamba Tuhan yang terpandang dan salam kapada dua jemaat dicatat sebagai bagian dari penutup surat Roma, dimana Paulus memperkenalkan Febe dan memberikan salam kepada beberapa orang yang dikenalnya di Roma. Dari 27 nama yang di sebut, hanya sebelas orang yang di beri penghargaan dengan pujian, misalnya "yang telah berkerja keras" atau "yang telah berkerja". Dari segi latar belakang sosial jemaat-jemaat di Roma, kebanyakan dari nama itu, yang dicatat dalam pasal Roma 16:3-15, adalah nama budak atau mantan budak, dan hanya satu nama yaitu Yulia, yang merupakan nama asli Roma, tiga dari mereka jelas orang Yahudi, namun kemungkinan besar Priskila, Akwila, Maria, juga Rufus dan ibunya adalah orang Yahudi. Dari sini bisa dilihat jika injil Kristus lebih cepat berkembang di lapisan masyarakat rendah di Roma, tetapi kemungkinan besar mereka sempat mengadakan perjalanan keluar Italia sehingga mereka mengenal Paulus. Salam tersebut kemudian di akhiri dengan berkat kasih karunia Allah. Struktur tersebut merupakan saluran penggenapan kasih karunia Allah dalam pengalaman rasul Paulus dan juga menggambarkan suasana keakraban di antara hamba Tuhan yang kagum akan kasih kerunia Allah terhadap orang yang dibenarkan karena iman. Teladan yang pantas ditiru oleh hamba Tuhan adalah dimana seseorang tersebut bersedia menolong orang lain yang dalam kekurangan, saling menghormati dan mendukung rekan sekerja dalam perjuangan menyampaikan injil Kristus, sama seperti Priskila dan Akwila yang telah mempertaruhkan nyawanya dengan di penjara bersama dengan nya. ${ }^{17}$

${ }^{17}$ Dave Hagelberg, Tafsir Roma Dari Bahasa Yunani (Bandung: Kalam Hidup, 2013). hal 17-24. 
Ketujuh, makna salam surat Paulus kepada Jemaat di Kolose 1:1 Pada waktu Perjanjian Baru ditulis, telah menjadi suatu kebiasaan untuk memulai sebuah surat dengan menyebutkan nama penulis surat tersebut. Seperti Paulus misalnya. Ia memperkenalkan dirinya sebagai rasul Kristus Yesus, Rasul Paulus menyusuri asal kerasulannya sampai kembali kepada kehendak Tuhan (lihat juga Kis. 9:15; Gal. 1:1). Pekerjaan ini bukanlah yang ia pilih bagi dirinya sendiri atau karena ia telah dilatih oleh manusia. Jabatan ini juga tidak diberikan kepadanya oleh pentahbisan manusia. Kedudukan ini tidak "berasal dari manusia" (sebagai sumber), dan juga tidak "datang melalui manusia" (sebagai alat). Melainkan, semua pelayanannya dikerjakan dibawah suatu kesadaran serius bahwa Tuhan sendiri telah memilihnya sebagai rasul. Bersama Paulus pada saat Surat ini ditulis adalah Timotius saudara kita. Sangatlah baik jika kita perhatikan bahwa disini sama sekali tidak ada kesan kekuasaan dan penguasaan jabatan dalam sikap Paulus terhadap Timotius. Keduanya adalah anggota suatu persaudaraan dan tidak terpikir harus ada hirarki dengan pembesar-pembesar gerejawi yang punya gelar-gelar muluk dan pakaian istimewa.

Di ayat ke dua, Surat ini dialamatkan kepada saudara-saudara yang kudus dan yang percaya dalam Kristus di Kolose. Ada dua nama yang indah di sini yang diberikan di dalam Perjanjian Baru kepada setiap pengikut Kristus. Saudara-saudara yang kudus berarti mereka dipisahkan bagi Tuhan dari dunia dan sebagai akibatnya mereka seharusnya hidup kudus. Saudara-saudara yang percaya atau yang setia dalam terjemahan NKJV menunjukkan bahwa mereka adalah anak-anak dari Ayah yang sama melalui iman di dalam Tuan Yesus; mereka saudara-saudari seiman. Orang Kristen juga disebut 'murid' dan 'orang percaya' dalam bagian lainnya di Perjanjian Baru.

Kemudian Rasul Paulus menyapa orang-orang kudus ini dengan sapaan salam yang penuh kasih: kasih karunia dan damai sejahtera dari Tuhan, Bapa kita, menyertai kamu dalam bahasa Yunani dan terjemahan NKJV, ayat 2 memasukkan "dan Tuan Yesus Kristus". Tidak ada dua pernyataan yang lebih dapat memeluk berkat-berkat dari Kekristenan kecuali dua pernyataan ini, yaitu kasih karunia dan damai sejahtera. Kasih karunia adalah salam umum orang Yunani, dan pernyataan damai sejahtera digunakan oleh orang Yahudi, kedua-duanya dipakai pada waktu bertemu atau berpisah. Rasul Paulus menggabungkan keduanya dan meninggikan makna serta penggunaannya. Kasih karunia menggambarkan Tuhan membungkuk kepada manusia yang 
berdosa dan tersesat, dengan suatu keharuan yang lembut dan penuh kasih. Damai sejahtera menyimpulkan semua akibat yang terjadi di dalamnya. ${ }^{18}$

Kedelapan, makna salam kitab Efesus, dimana Paulus menyatakan jika ia adalah seorang rasul oleh Kehendak Allah, mengenai penyataan tersebut hal yang ingin ia tekankan adalah bahwa ia adalah kepunyaan Kristus, hidupnya bukan lagi untuk kehendaknya sendri melainkan milik Kristus dan harus hidup sesuai dengan apa yang Kristus kehendaki. Bagian salam ini juga menerangkan jika ia di utus untuk melakukan tugas khusus dan sepanjang hidupnya ia bertugas bagi Kristus. Kekuatan yang ia miliki merupakan dari pada Kristus. Ungkapan Kasih Karunia dan Damai sejahtera juga Paulus berikan dimana kasih karunia adalah pemberian kepada seseorang yang sesungguhnya tidak berhak memperolehnya, dan damai sejahtera yang merupakan sesuatu yang bebas dari sifat lahiriah yang bukan bersumbar dari materi duniawi namun merupakan damai yang bersumber saat seseorang melakukan kehendak Allah didalam kehidupannya. ${ }^{19}$

Kesembilan, Salam dalam kitab 1 dan 2 Timotius 1:1-2 dimana walaupun surat tersebut ditujukan kepada Timotius secara pribadi namun hal tersebut di maksudkan supaya lewat mereka petunjuk yang di berikan tersebut di berikan kepada jemaat untuk mengatur kehidupan dan tata gereja, petunjukpetunjuk tersebut didukung oleh kewibawaan kerasulan Paulus. Hal tersebut di tegaskan Kembali dalam salam penutup yaitu "Kasih Karunia menyertai kamu" (dalam bentuk jamak yang artinya ditunjukan kepada seluruh jemaat bukan hanya kepada timotius saja. Dalam ayat yang kedua Kasih Karunia, rahmat dan damai ini merupakan ungkapan salam yang berlaku di kalangan umat Kristen zaman itu (II Tim 1:2) namun Paulus sendri lebih menyukai salam dalam bentuk pendek yaitu "kasih karunia dan damai sejahtera". Kasih karunia adalah anugerah yang merupakan kata kunci theologi Paulus yang juga menjiwai seluruh surat pastoral, dan kasih karunia tersebut menghasilkan keselamatan bagi orang berdosa (Ef 2:8). Dimana hubungan antara manusia dan Allah di pulihkan oleh kasih karunia yang menyelamatkan, di situlah timbul damai sejahtera. ${ }^{20}$

Kesepuluh, Makna salam dalam kitab Titus 1:1-4 dimana tertulis dari Paulus, hamba Allah dimana dengan sebutan ini Paulus hendak menyatakan

${ }^{18}$ William Macdonald, "Surat Kepada Jemaat Di Kolose," https://studylibid.com/doc/867619/surat-kepada-jemaat-di-kolose-pendahuluan. Diakses 28 April 2020

${ }^{19}$ William Barclay, Pemahaman Alkitab Setiap Hari; Surat Galatia Dan Efesus (Jakarta: Bpk Gunung Mulia, 2017) hal. 109-110.

${ }^{20}$ Budiman, Surat 1\& 2 Timotius Dan Titus.hal. 126-127. 
bahwa apa yang ia lakukan adalah dalam pelayanan kepada Allah, dan dalam pasal ke 2 jika di hubungkan dengan tugas rasul yang adalah memberitakan harapan akan hidup yang kekal,sedangkan di ayat yang ka 4 dikatakan jika Titus merupakan anak yang sejati, karena ia menjadi orang kepercayaan Paulus dimana Titus sendiri dipercayai oleh Paulus untuk memulihkan hubungannya dengan jemaat Korintus yang tadinya retak oleh pertentanganpertentangan (II korintus 7:6-13). ${ }^{21}$

\section{Implementasi Bagi Pelayan Tuhan}

Dalam bahasa asli Perjanjian Baru ada beberapa kata yang mengandung makna pelayan yaitu doulos, huperetes, diakonos, oiketes, therapon, dan leitourgos. Sedangkan ada dua kata lain yaitu misthios dan misthotos namun kurang tepat iika di pakai dalam konteks pelayan Tuhan karena keduanya jika diterjemahkan adalah "orang upahan". Dengan melihat makna dan pengguanaan kata tersebut dalam konteks gereja mula-mula, maka seseorang dapat menemukan jawaban bagaimana seharusnya seseorang melayani. Jika dilihat dari kata "doulos" hal ini tentu akan merujuk kapada ketergantungan seorang budak kapada tuannya, dan juga mengandung arti komitmen total kepada tuannya atinya seorang "doulos" tidak bisa mengabdi kepada dua tuan. Jika dilihat dari makna tersebut maka Pelayan Tuhan adalah hamba Kristus, yang sadar bahwa hidupnya adalah milik Kristus, dan hamba Tuhan harus memiliki komitmen kepada satu tuan, yaitu Kristus serta memiliki ketaatan dan kerendahan hati. ${ }^{22}$ Dari setiap penjabaran salam Paulus dalam surat-suratnya ada beberapa poin penting yang dapat dijadikan sebagai bahan implementasi atau penerapan dalam pelayanan saat ini yang memperlengkapi hamba Tuhan dalam melayani dan membangun hubungan dengan jemaat. Beberapa poin tersebut adalah sebagai berikut;

Pertama, dalam setiap suratnya Paulus menyadari panggilannya sebagai seorang rasul, hal ini dilihat dari beberapa pendahuluan salam dalam suratnya dimana ia menyatakan bahwa panggilan rasul tersebut adalah pilihan Tuhan atas dirinya sebagai hamba Kristus, seseorang yang dikasihi dan diterima sebagai anak sehingga ia melakukan pelayanannya dengan penuh sukacita. ia tidak pernah menggunakan kekuasaannya sebagai rasul dan tidak akan ada kekecewaan baginya melainkan ada sukacita yang dalam yang rasul Paulus rasakan. Sebab segala sesuatu yang ia lakukan adalah untuk membangun dan bukan untuk menghancurkan. Disiplin harus selalu diarahkan

${ }^{21}$ Ibid. hal. 128.

${ }^{22}$ Asih Rachmani, "Konsep Pelayan Tuhan Perjanjian Baru Dan Penerapannya Pada Masa Kini.," Teologi dan Pelayanan Kristiani 3, no. 2 (2019): hal. 100. 
untuk membangun seseorang bukan malah menjatuhkan. Oleh sebab itu hendaklah kita saat ini melayani dengan penuh kesetiaan, mengingat bahwa seseorang terpanggil menjadi seorang hamba itu karena ia telah dipilih oleh Allah sendiri dan hendaklah seseorang melayani dengan penuh ketulusan hati bukan karena terpaksa. jadi Hamba Tuhan harus mengetahui dengan benar makna dari pelayanan itu sendiri, cara yang benar, sesuai dan tepat agar dapat mencapai tujuan yang tepat. ${ }^{23}$

Kedua, salam adalah sesuatu yang penting bagi Paulus karena menunjukan suatu etika dalam berkomunikasi, sebagai respon akan kehadiran orang lain serta menunjukan perhatian melalui ucapan berkat dan harapan bahkan peringatan bagi setiap penerima surat tersebut, dan wujud dari kelemah lembutan serta kerendahan hati dilihat dari surat yang diawali dengan salam dan di akhiri dengan juga dengan salam, dan juga gambaran tentang kedekatan Paulus dengan hamba Tuhan lainnya saat itu seperti contohnya Timotius dimana tidak ada unsur hirarki didalam gereja, tidak ada yang lebih hebat, melainkan semua hamba Tuhan adalah saudara. dimana ia juga memberikan penghargaan maupun pujian bagi setiap orang yang telah berkerja keras untuk membantu dalam pelayanan dan menggambarkan suasana keakraban di antara hamba Tuhan. Seseorang yang melayani saat ini haruslah memiliki kerendahan hati seperti seorang Paulus yang melaksanakan pelayanannya dengan penuh rasa ucapan syukur, atas keselamatan yang di anugrahkan Allah kepadanya. Tidak mencari keuntungan bahkan bergantung kepada kedudukan yang diperoleh dari pelayanan tersebut, melainkan hidup patuh kepada Allah Bapa. Senantiasa memperkatakan hal yang baik bagi semua orang yang ditemui, saling menguatkan iman satu dengan yang lain. ${ }^{24}$

Ketiga, Paulus senantiasa menyelipkan inti injil Kristus dalam setiap suratnya sesuai dengan misi Paulus untuk memberitakan kabar baik. Dilihat dari pemakaian istilah Kasih Karunia "Kharis" yang berbicara tentang Kasih Karunia melalui pengorbanan Kristus di kayu salib yang merupakan anugarah bagi setiap orang tanpa terkecuali, yang mendatangkan sukacita, kemurahan dan kebaikan. Serta Damai Sejahtera "Eirene" yang merupakan sesuatu hal yang diterima jika Kasih Karunia tersebut telah diperoleh orang berdosa yaitu

${ }^{23}$ Joko Santoso, "Pelayanan Hamba Tuhan Dalam Tugas Penggembalaan Jemaat," Sanctum Domine: Jurnal Teologi 9, no. 1 (2020): hal. 4.

${ }^{24}$ Natanael S. Prajogo, "Implementasi Kepemimpinan Gembala Yang Melayani Berdasarkan 1 Petrus 5:2-10 Di Kalangan Gembala Jemaat Gereja Bethel Indonesia SeJawa Tengah," HARVESTER: Jurnal Teologi dan Kepemimpinan Kristen 4, no. 1 (2019): hal. 12. 
berupa keselamatan dan kebahagiaan sebagai wujud perdamaian antara Allah dan manusia serta sesamanya. Salib merupakan hal yang paling penting bagi Paulus karena salib merupakan titik peralihan hidup manusia dan salib merupakan tempat pertukaran dimana hukum atas manusia berdosa ditimpakan kapada Yesus, agar mereka yang percaya tidak menerima hukuman melainkan di benarkan oleh Allah. Oleh sebab itu hendaklah hal ini dapat senantiasa di perkatakan oleh setiap pelayan Tuhan saat ini mengenai ucapan Kasih Karunia bagi semua orang yang ditemui sehingga setiap orang menyadari akan makna Kasih Karunia yang di anugarahkan kepadanya. ${ }^{25}$

Keempat, Paulus sendiri belum pernah bertemu secara fisik dengan jemaat di Roma dan tidak berhubungan langsung dengan jemaatnya. Namun Paulus membangun kedekatan yang baik dengan penerima surat tersebut, gaya penulisan salam dalam surat Roma yang menggunakan pujian di awal surat dipandang sebagai sebuah usaha membangun kedekatan kepada jemaat. Dalam hal inilah Paulus menunjukan sikap keteladanan kepada setiap hamba Tuhan dimanapun berada agar senantiasa membangun pendekatan dengan bijak dan penuh kasih sehingga pelayanan kita dapat diterima dan diserap baik oleh orang yang dilayani. Penerimaan yang baik sangat mempengaruhi kesuksesan pemberitaan Injil, sehingga Injil dapat bertumbuh dan berbuah dalam jemaat dan oleh karenanya nama Tuhan Yesus senantiasa dipermuliakan.

\section{KESIMPULAN}

Berdasarkan pembahasan mengenai makna salam dalam tulisantulisan Paulus maka penulis mendapatkan ada beberapa poin kesimpulan yang bisa di jadikan sebagai refleksi bagi setiap hamba Tuhan dalam ladang pelayanan. Dapat disimpulkan makna salam yang ditulis oleh Paulus memiliki arti;

Pertama, salam menunjukan harapan berkat bagi orang lain, didalam salam kita diajarkan untuk memberkati sebagai saudara dalam kasih karunia Allah.

Kedua, makna salam mengandung arti seperti Paulus yang mendapatkan otoritas kerasulanya dari Allah demikian juga hendaknya hamba Tuhan. dalam hidupnya berlandaskan kedaulatan Allah dan melayani Tuhan dengan segenap hati.

${ }^{25}$ David Eko Setiawan and Dwiati Yulianingsih, "Signifikansi Salib Bagi Kehidupan Manusia Dalam Teologi Paulus," FIDEI: Jurnal Teologi Sistematika dan Praktika 2, no. 2 (2019): hal.111. 
Ketiga, makna salam menurut Paulus adalah bagaimana menghargai dan memberikan perhatian kepada orang-orang yang telah berjerih lelah dalam memdukung pelayanan.

Keempat, melalui makna salam dalam setiap surat-surat Paulus seorang hamba Tuhan perlu membangun kedekatan dan menciptakan hubungan yang baik dengan jemaat, karena keberhasilan dalam pelayanan dimulai dari hubungan yang baik bisa dari hal-hal yang kecil bagaimana pelayan Tuhan masa kini memperlakukan jemaat dengan penuh ramah, kasih mesra dan menghindari sikap mementingkan diri sendiri. Dengan demikian Paulus telah mengajarkan suatu standar yang ideal bagi hamba-hamba Tuhan didalam pelayanannya.

\section{KEPUSTAKAAN}

Abineno, J.L.CH. Surat Filipi. Jakarta: Bpk Gunung Mulia, 2015. Barclay, William. Pemahaman Alkitab Setiap Hari; Surat 1dan 2 Korintus. Jakarta: Bpk Gunung Mulia, 2012.

_. Pemahaman Alkitab Setiap Hari; Surat Galatia Dan Efesus. Jakarta: Bpk Gunung Mulia, 2017.

. Pemahaman Alkitab Setiap Hari; Surat Roma. Jakarta: Bpk Gunung Mulia, 2007.

Bratcher, Robert G. Surat-Surat Paulus Kepada Jemaat Di Kolose Kepada Filemon. Jakarta: LAI dan Yayasan Karunia Bakti Budaya Indonesia, 2019.

Budiman, R. Surat 1\& 2 Timotius Dan Titus. Jakarta: Bpk Gunung Mulia, 2016.

Hagelberg, Dave. Tafsir Roma Dari Bahasa Yunani. Bandung: Kalam Hidup, 2013.

J. Wesley Brill. Tafsiran Surat Tesalonika. Bandung: Yayasan Kalam Hidup, 2008.

Kalangit, Wenas. "SURAT-SURAT PAULUS." Gereja Kristen Indonesia. Last modified 2007. http://www.gkikavpolri.or.id/site/surat-surat-paulus-oleh-dr-wenas-kalangit/.

Macdonald, William. "Surat Kepada Jemaat Di Kolose." https://studylibid.com/doc/867619/surat-kepada-jemaat-dikolose-pendahuluan.

Marxsen, Willi. Pengantar Perjanjian Baru: Pendekatan Kritis Terhadap Masalah-Masalahnya. Jakarta: Gunung Mulia, 2008.

Prajogo, Natanael S. "Implementasi Kepemimpinan Gembala Yang Melayani Berdasarkan 1 Petrus 5:2-10 Di Kalangan Gembala Jemaat Gereja Bethel Indonesia Se-Jawa Tengah." HARVESTER: Jurnal Teologi dan Kepemimpinan Kristen 4, no. 1 (2019). 
Rachmani, Asih. "Konsep Pelayan Tuhan Perjanjian Baru Dan Penerapannya Pada Masa Kini." Teologi dan Pelayanan Kristiani 3, no. 2 (2019).

Santoso, Joko. "Pelayanan Hamba Tuhan Dalam Tugas Penggembalaan Jemaat." Sanctum Domine: Jurnal Teologi 9, no. 1 (2020).

Scheunemann, Rainer. Surat Paulus Kepada FILEMON. Jakarta: Bpk Gunung Mulia, 2016.

Setiawan, David Eko, and Dwiati Yulianingsih. "Signifikansi Salib Bagi Kehidupan Manusia Dalam Teologi Paulus." FIDEI: Jurnal Teologi Sistematika dan Praktika 2, no. 2 (2019).

Situmorang, Jonar. "Model Misi Perkotaan Rasul Paulus Di Korintus." Missio Ecclesiae 7, no. 2 (2018).

Sugiono. Memahami Penelitian Kualitatif. Bandung: CV Alfabeta, 2016.

"Salam." Wikipedia Ensiklopedia Bebas. https://id.wikipedia.org/wiki/Salam.

"Salam." Last modified 2019. https://saatteduh.wordpress.com/2019/05/09/salam/.

"Studi Kamus." Alkitab Sabda. 